understand her. I wrote to her asking her to see me first and then decide whether I could help her or not. She did and we had a successful therapeutic relationship over time. Now when I read of demands for 'culturally separate services' (Bhui \& Sashidharan, 2003), I feel that my White colleagues are being told: I am equal to you but you are not equal to me.

The debate has so far been conducted in a Black and White manner, with psychiatrists seen as oppressors and patients as victims. People drawing such caricatures see themselves as the moral guardians of public institutions, combating the evil of racism in all its forms. They have two great advantages over practising clinicians. First, many of them have no responsibility for providing care. Such power without responsibility must be exercised judiciously, especially when the welfare of the vulnerable is at stake. Those who do practise psychiatry while berating it for being 'eurocentric' and racist, never provide alternatives of proven efficacy to standard psychiatric care. Second, vested interests are supposed to reside only within the psychiatric sphere. No one questions the vested interest involved in high-profile committee memberships, the academic kudos and other trappings of power acquired simply by making allegations against psychiatry which cannot be defended, because to even challenge a charge of racism is to display racist tendencies.

If our patients are to receive the care they deserve, we need to make sound clinical judgement, free from bias and political fashion, the bedrock of our practice. Scientific evidence must be the basis on which we devise our treatments, not ideologies, especially those that are not penetrable by facts. Our patients are individuals with their own personal strengths and vulnerabilities, and must not be reduced to ideological battlegrounds where political and cultural wars are fought. Moreover, if psychiatry is to get the leadership it deserves, perhaps we should all speak out when we feel that scientific objectivity and clinical reasoning are being made subservient to political considerations and expediency.

\section{Declaration of interest}

\& debate

S.P.S. runs an early intervention service in a multi-ethnic area in Birmingham.

\section{Acknowledgements}

I am grateful to Professor Tom Burns and Dr Christina Pourgourides for their comments on the initial draft of the paper.

\section{References}

BHUI, K. \& SASHIDHARAN, S. P. (2003) Should there be separate psychiatric services for ethnic minority groups? British Journal of Psychiatry, 182,10-12. DEPARTMENT OF HEALTH (2005) Delivering Race Equality in Mental Health Care: An Action Plan for Reform Inside and Outside Services and the Government's Response to the Independent Inquiry into the Death of David Bennett. Department of Health.

HOLLINS, S. \& MOODLEY, P. (2006) Racism in mental health. http:// www.bmj.com/cgi/eletters/333/ 7569/648

MCKENZIE, K. \& BHUI, K. (2007) Institutional racism in mental health care. BMJ, 334, 649-650.

McLAUGHLIN, K. (2007)

Multiculturalism: Bad for your Mental Health?http://www.spiked-online .com/index.php?/site/article/3046

MACPHERSON,W. (1999) The Stephen Lawrence Inquiry. TSO (The Stationery Office).

NORFOLK, SUFFOLK AND

CAMBRIDGESHIRE STRATEGIC HEALTH AUTHORITY (2003) Independent Inquiry into the Death of David Bennett. Norfolk, Suffolk and Cambridgeshire Staregic Health Authority.

RITCHIE, J., DICK, D. \& LINGHAM, R. (1994) The Report of the Inquiry into the Care and Treatment of Christopher Clunis. TSO (The Stationery Office).

SASHIDHARAN, S. P. (2003) Inside Outside: Improving Mental Health Services for Black and Minority Ethnic Communities in England. Department of Health.

SINGH, S. P. \& BURNS, T. (2006) Race and mental illness: there is more to race than racism. BMJ, 333, 648-651.

Swaran P. Singh Professor of Social and Community Psychiatry, Health Sciences Research Institute, University ofWarwick, Warwick CV4 7AL, email: S.P.Singh@ warwick.ac.uk

\title{
Searching for racists under the psychiatric bed: Commentary on ... Institutional racism in psychiatry ${ }^{\dagger}$
}

In our view, Professor Singh's article (2007) is one of the most important papers to appear in the Bulletin in recent years. Singh \& Burns (2006) have been very courageous in challenging the idea that British psychiatry is institutionally racist, and not unexpectedly have provoked reaction. What has been more surprising is the extent to which this has provoked strong criticism of Professor singh among psychiatric colleagues.

Over the past 15 years, there have been at least nine reports from government and voluntary agencies on the high rates of psychosis and compulsory detention among African-Caribbean people living in the UK. Psychiatrists have striven to divest themselves of any hint of racism in their practice, and cultural training has become mandatory for all staff. Yet the high rates persist, even in trusts where White English-born psychiatrists and nurses are in a minority. Importantly, the clamour about institutional racism has obscured the real causes of the increased incidence of schizophrenia and mania among British African-Caribbeans. Sadly, therefore, appropriate action
† See pp. 363-365, 367-370 and 397398 , this issue. 
has not been taken, and too many people from this community continue to fall ill and to have less than optimum care.

Recent large studies such as the AESOP study (e.g. Morgan et al, 2007) and the Count Me in Census (Healthcare Commission, 2007) have demonstrated that the causes do not predominantly lie in psychiatry but rather in wider society. Simply put, the AESOP study has shown that African-Caribbean people living in the UK are more likely to be exposed to factors known to increase risk of psychosis than are White or Asian people. Thus, growing up in the inner city, being separated from a parent or suffering physical abuse in childhood, as well as adult factors associated with social exclusion (unemployment, living alone, having no support from family or friends) are all more common among patients with psychosis from African-Caribbean than other communities; similarly, cannabis use is highest in people of Caribbean (and lowest in those of Asian and African) origin. It is likely that experience of racial discrimination in society also plays a role, although why the rates are so much higher in the African-Caribbean than in the Asian population is unclear when this factor is likely to operate in both communities.

Of course, this does not explain the greater proportion of compulsory admissions among those of Caribbean origin. However, the 2006 Count Me In Census has now shown that this is a direct result of the greater likelihood of African-Caribbean patients being referred to psychiatric units via the courts or police; not surprisingly, such patients are less likely to be willing to be admitted voluntarily. In contrast, Black patients referred through the normal channels are no more likely to be sectioned than their White counterparts.

Thus, the foundations of the case for institutional racism have been seriously undermined. The reaction of its proponents has been to attempt to suppress or discount the data, and to attempt to brand those producing the evidence as racist. However, this strategy is less effective than it used to be. Five years ago one of us (R.M.M.) chaired a debate on this topic at the Institute of Psychiatry. Three hundred people listened to a series of diatribes against the very services which were attempting to help African-Caribbean people with severe mental illness. Not one single White professional spoke up to defend the psychiatric services, but over the next few days many colleagues made it clear that they had been dismayed by the one-sided nature of the debate. When asked why they had not spoken up, each said that they were afraid to be labelled as racist. Six months ago at a debate on the same topic, there was a lively discussion in which the evidence-free polemics of the institutionally racist lobby were widely challenged. There has indeed been a change in the tide of opinion, and this year even the Department of Health has reversed its previous policy and decided that that it is inappropriate to apply the term institutional racism to psychiatry.

There may be a minority of individuals in psychiatry who are racist, as there are in society as a whole. But much more vocal are those whose perception of reality is so distorted by examining all topics through the prism of racist thinking that they interpret all differences between ethnic groups in racist terms. Some have even gone so far as to advocate separate psychiatric services for individuals of different races, a proposal to our minds reminiscent of South Africa in the worst days of apartheid. No doubt they also interpret the high admission rates for alcoholism among Scottish and Irish males such as ourselves as evidence of English psychiatrists misdiagnosing the Scots and Irish because of their failure to understand the important symbolic role of drunkenness in Celtic culture. We are happy to drink to the demise of such distorted thinking and to Swaran Singh's courage in challenging the myth that British psychiatry is systemically racist.

\section{Declaration of interest}

None.

\section{References}

HEALTHCARE COMMISSION (2007) Count Me In Census 2006. Healthcare Commission. http://www. healthcarecommission.org.uk/ nationalfindings/ nationalthemedreports/mentalhealth/ countmein/2006.cfm

MORGAN, C., KIRKBRIDE, J., LEFF, J., et al (2007) Parental separation, loss and psychosis in different ethnic groups: a case-control study. Psychological Medicine, 37, 495-503.

SINGH, S. P. \& BURNS,T. (2006) Race and mental illness: there is more to race than racism. BMJ, 333, 648-651.

*Robin M. Murray Professor of Psychiatry, Institute of Psychiatry, King's College, London SE5 8AF and Visiting Professor, University of the West Indies, email: robin.murray@iop.kcl.ac.uk, Paul Fearon Senior Lecturer, Institute of Psychiatry, King's College London and Consultant Psychiatrist, South London and Maudsley NHS FoundationTrust, London 